\title{
UM PULO BENJAMINIANO À ORIGEM
}

\author{
Helano Ribeiro \\ Universidade Federal de Santa Catarina / CAPES
}

\begin{abstract}
RESUMO
Este artigo tem o intuito de armar uma análise acerca da escritura do austríaco Thomas Bernhard, em especial, com sua autobiografia - sua experiência traumática na Segunda Guerra Mundial - cujo título Origem já nos arrebata para questões do teórico Walter Benjamin e seu Ursprung [Origem - pulo primeiro] anacrônico. A questão da origem, explicitada por Bernhard, revela-se menos no âmbito da gênese [Entstehung], descendência [Herkunft], do que em uma leitura dialética da história no tempo de aqui e agora, momento presente - das reminiscências do discurso nacional-socialista que ainda reverbera. Sua estética da repetição parece ser a tática de inoperância deste mesmo discurso. A escrita de si de Bernhard aponta, ainda, para um sistema de ensino, baseado em vigilância e punição, que mostra pouco ter mudado após o período da guerra.
\end{abstract}

PALAVRAS-CHAVE: Thomas Bernhard. Walter Benjamin. Ursprung. Estética da repetição.
ABSTRACT
This article aims to set up a review about the writing of the Austrian Thomas Bernhard, especially his autobiography - a traumatic experience in World War II whose title already Origin snatches the theoretical issues to Walter Benjamin and his anachronistic Ursprung [Origin - leap first]. The question of the origin explained by Bernhard seems to move less under the genesis [Entstehung] descent [Herkunft] than in a dialectical reading of history the time here and now, the present moment - the reminiscences of the nationalsocialism discourse that still reverberates. His aesthetic of repetition seems to be the tactic of inoperation of this same speech. His autobiography also points to an education system based on surveillance and punishment, which seems to have not changed after the period of World War II.

KEYWORDS: Thomas Bernhard. Walter Benjamin. Ursprung. Aesthetic of repetition.

Recebido: 16/06/2013

Aprovado: 30/08/2013

Helano Ribeiro <hjcribeiro@gmail.com> é doutorando em Literatura na Universidade Federal de Santa Catarina. 


\title{
UM PULO BENJAMINIANO À ORIGEM
}

\author{
Helano Ribeiro
}

\section{INTRODUÇÃO}

Thomas Bernhard [1931-1989] foi, talvez, o traidor mais feroz do Estado da Áustria, o filho infame mais odioso de um país, que, segundo ele, ainda se fazia guiar pelo pensamento nacional-socialista. Em sua extensa obra - narrativas de histórias doentias: romances, peças, contos e uma autobiografia reunida em cinco volumes - neste discurso enciclopédico, coabitam suicidas, psicopatas, marginalizados, neuróticos, obsessivos compulsivos, desesperados à beira do abismo, que parecem desarmar o estranhamento de um mundo - que lhes é totalmente alheio - e a alienação intelectual existentes na Literatura Alemã desde 1945.

Bernhard sempre foi considerado um escritor polêmico, mantendo uma relação de amor e ódio com a Áustria. 0 ressentimento se faz presente através de um testamento no qual proíbe a publicação de qualquer obra póstuma - como cartas e anotações - em território austríaco. Dois dias antes de sua morte, Bernhard procura o tabelião na cidade de Salzburgo com o objetivo de elaborar seu testamento:

Fica expresso de modo veemente o fato de eu não ter nada a ver com a Áustria e, posiciono-me não somente contra qualquer interferência, mas também contra qualquer aproximação da Áustria que atinja meu trabalho futuro. Depois de minha morte, fica proibida a publicação de qualquer material literário póstumo, 


\section{um pulo beniuminino dor \\ helano ribeiro

sejam cartas ou anotações, nenhuma palavra deve ser publicada. ${ }^{1}$

Mesmo após sua morte, suas obras, especialmente as peças para o teatro, foram objeto de controvérsia, aí incluída, talvez a mais conhecida e comentada entre os críticos, Heldenplatz [Praça dos Heróis] ${ }^{2}$, de 1988, na qual Bernhard denuncia o ressentimento antissemita ainda remanescente na Áustria pós-guerra. A peça de Bernhard mostra, através do suicídio de um simples professor de matemática, na mesma praça, 50 anos depois do discurso do Führer, proferido na mesma praça, as vozes do nacional-socialismo que ainda reverberam. Assim, se fará necessário falar de memória.

Para falar de memória: não há recordação do passado, mas um sequestro seu pelo presente. Para falar de memória: é preciso pensar nessa clausura, resultado do atropelo entre os movimentos de ida e volta ao passado. A anamnese não é passiva, ela é não somente uma tentativa de restaurar o passado "mas também uma transformação do presente tal que, se o passado perdido aí for reencontrado, ele não fique o mesmo, mas seja, ele também, retomado e transformado."3 Pensando com Jeanne Marie Gagnebin, a rememoração proclama a salvação, ela pode expor os restos, revelar o feio, o abjeto, a face melancólica dos anjos entediados, restaurar os elementos quase perdidos e devolver-lhes à superfície no tempo-de-agora, momento presente, num gesto de redenção ao modo da arte barroca. ${ }^{4}$ Essa escavação arqueoló-

1 „Ausdrücklich betone ich, da $\beta$ ich mit dem österreichischen Staat nichts zu tun haben will und ich verwahre mich nicht nur gegen jede Einmischung, sondern auch gegen jede Annährung dieses österreichischen Staates, meine Person und meine Arbeit betreffend in aller Zukunft. Nach meinem Tod darf aus meinem eventuell gleich wo noch vorhadenen literarischen Nachla $\beta$, worunter auch Briefe und Zettel zu verstehen sind, kein Wort mehr veröffentlicht werden." HOELL, Joachim. Thomas Bernhard. München: dtv, 2000, p. 7. [Todas as traduções do alemão são minhas].

2 Nenhuma de suas muitas peças foi publicada no Brasil.

3 GAGNEBIN, Jeanne Marie. História e narração em Walter Benjamin. São Paulo: Perspectiva, 1999, p. 16.

4 Em Origem do drama trágico alemão, Benjamin trabalha com a ideia de que o drama trágico, ao contrário do que se possa afirmar, não está enraizado no mito, mas na história. Historicidade, com toda implicação de texturas político-sociais e de referência, gera tanto conteúdo como estilo. Sentindo-se sugado na direção do abismo da condenação, uma condenação registrada profundamente num sentido carnal, o dramaturgo barroco, alegorista, 
gica das memórias não deixa de se revelar saturnina ${ }^{5}$, pois que implica no maquinar de um passado incômodo, indesejado.

\section{O ATROPELO DE CHRÓNOS — UMA AGORIDADE CHEIA DE HISTÓRIA}

A obra autobiográfica de Thomas Bernhard, composta de cinco livros, não se encerra em uma cronologia linear, visto que o último dos cinco livros publicados pelo autor austríaco, intitulado Uma criança [1982], é um retorno à infância inicial, essa talvez a fase mais feliz de sua vida. A publicação no Brasil reunida em um único volume, no entanto, optou pela ordem cronológica dos fatos de sua vida em detrimento da ordem de publicação, partindo de Uma criança e seguindo em direção à fase mais madura de Bernhard.

No lugar de um relato que chegaria aos últimos anos de vida do autor de Frost, ele prefere voltar às memórias de uma infância inicial, dando um pulo sobre os anos de luta contra uma tuberculose pulmonar intratável - um intruso - que marcaria todo o seu trajeto como escritor. Não acredito ser obra do acaso, também, o fato de o último volume escrito e publicado de sua autobiografia, as $U r$-memórias [memórias primevas] de sua origem, ser o menos soturno, pois trata das primeiras recordações pueris, antes da entrada traumática na escola nacional-socialista e a experiência da Segunda Guerra, fato que só vem descrito ao final do livro, como uma forma de marcar o fim das atividades lúdicas para a entrada gradual na escola de orientação nacional-socialista. No Brasil, os cinco volumes levam o título único: Origem. 0 que se sugere é que o autor de $O$ náufrago procura, através desse Ur-Sprung [pulo

historiógrafo e as personagens que ele anima se grudam fervorosamente ao mundo. Associado às vanguardas modernas, Benjamin foi, no entanto, formado decisivamente pela visão barroca da história que ele procuraria transpor para o entendimento da própria modernidade. A leitura de Benjamin consiste em fazer uma analogia entre barroco e modernidade procurando mostrar especialmente a semelhança de condições históricas vividas pelo barroco e pelo moderno: a situação de dissolução de todas as certezas e fundamentos últimos.

5 Como regente da melancolia encontramos o planeta Saturno, considerado "o planeta mais maligno". AGAMBEN, Giorgio. Estâncias. A palavra e o fantasma na cultura ocidental. Trad. Selvino Assmann. Belo Horizonte: Editora UFMG, 2007, p. 36. 
original], retornar à origem, ou à origem da origem. Não se trata de Entstehung [gênese], tampouco de Herkunft [procedência]. A origem de que fala Bernhard é, sobretudo, uma leitura a contrapelo da história.

Uma das propostas deste artigo é a análise de suas memórias, pensando-as como um relato, acima de tudo, como uma leitura crítica, dialética, de uma história, cujas ruínas se estendem até o tempo do aqui e agora - uma agoridade cheia de história —, de modo que o alemão Walter Benjamin surge como um importante norte teórico em nossa análise. Imprescindível e, talvez, urgente, o apelo ao pensamento do berlinense para uma compreensão da questão da origem. 0 Ursprung é, possivelmente, um dos conceitos mais importantes de seu trabalho crítico, peça central do prefácio epistemológico que abre o livro Origem do drama trágico alemão. A origem coloca em cena um ritmo outro, uma dança às avessas, a saber, um movimento anacrônico, que se revela em forma de iluminação e ruptura, ela questiona, deste modo, a história em sua forma aufgehoben ${ }^{6}$ [conservada, cancelada] e seu desenvolvi-

6 Indispensável, embora que brevemente comentado, falar sobre a questão da história segundo Hegel e seu conceito de Aufhebung [supressão, conservação]. Em Fenomenologia do espírito, Hegel cria uma dialética não sintetizada, mas antes continuamente elevada a uma nova série de forças antinômicas, para isso, adia constantemente a síntese. Neste ponto, habita uma espécie de promessa em sua forma de potência - a preservação de uma dada dialética e a sua elevação a uma nova forma, trazendo uma teleologia da transcendência, de modo que, quando falamos em Aufhebung, pensamos em remoção, conservação, aperfeiçoamento, progresso. A tarefa da filosofia seria de fato compreender a autossupressão - sob a saída de luz das contradições internas. Hegel sugere um grande sistema filosófico em que o mundo, como Geist [espírito, intelecto], se encontraria em um processo cronológico da história de contínua superação. A teleologia proposta por ele será explicitada não somente pela análise da totalidade do universo, mas também pelos diversos processos e desenvolvimentos que o constituem, todos perpassados pela dialética, em que tendências antinômicas entram em contradição, resultando em uma síntese, mais perfeita e completa que as anteriores. Nesta visão, na história, os movimentos dialéticos se sucedem. Não é difícil de entender que esta corrente de pensamento, que busca um contínuo evolutivo da história e sua superação, vai de encontro à dialética benjaminiana e sua crítica a uma história progressista. Para tal, o pensador berlinense evoca a pintura de Paul Klee, o Angelus Novus, em sua nona tese sobre o conceito de história: "Há um quadro de Paul Klee que se chama Angelus Novus. Representa um anjo que parece querer afastar-se de algo que ele encara fixamente. Seus olhos estão escancarados, sua boca dilatada, suas asas abertas. 0 anjo da história deve ter esse aspecto. Seu rosto está dirigido para o passado. Onde nós vemos uma cadeia de acontecimento, ele vê uma catástrofe única, que acumula incansavelmente ruína sobre ruína e as dispersa a nossos pés. Ele gostaria de de- 
mento na esteira de Xoóvos [chrónos $]^{7}$ :

Mas, apesar de ser uma categoria plenamente histórica, a origem (Ursprung) não tem nada a ver com génese (Entstehung). "Origem" não designa o processo de devir de algo que nasceu, mas antes aquilo que emerge do processo de devir e desaparecer. A origem insere-se no fluxo do devir como um redemoinho que arrasta no seu movimento o material produzido no processo de gênese. 0 que é próprio da origem nunca se dá a ver no plano do factual, cru e manifesto. 0 seu ritmo só se revela a um ponto de vista duplo, que o reconhece, por um lado, como restauração e reconstituição, e por outro como algo de incompleto e inacabado. [...] A origem, portanto, não se destaca dos dados factuais, mas tem a ver com a sua pré- e pós-história. Na dialéctica inerente à origem encontra a observação filosófica o registo das suas linhas mestras. Nessa dialéctica, em tudo o que é essencial, a unicidade e a repetição surgem condicionando-se mutuamente. ${ }^{8}$

A restauração através do pulo não se dá de forma ilesa, mas se contenta com a ideia de que uma recuperação total do perdido é impossível. Jeanne Marie Gagnebin coaduna com essa ideia ao proferir em História e narração em Walter Benjamin que

\begin{abstract}
A origem benjaminiana visa, portanto, mais que um projeto restaurativo ingênuo, ela é, sim, uma retomada do passado, mas ao mesmo tempo - e porque o passado enquanto passado só pode voltar numa não identidade consigo mesmo - abertura sobre o futuro, inacabamento constitutivo. ${ }^{9}$
\end{abstract}

Pensando em sua forma vinculada à história, de acordo com Walter

ter-se para acordar os mortos e juntar os fragmentos. Mas uma tempestade sopra do paraíso e prende-se em suas asas com tanta força que ele não pode mais fechá-las. Essa tempestade o impele irresistivelmente para o futuro, ao qual ele vira as costas, enquanto o amontoado de ruínas cresce até o céu. Essa tempestade é o que chamamos de progresso". BENJAMIN, Walter. Sobre o conceito de história. In: Magia e técnica, arte e política. Ensaios sobre literatura e história da cultura. Trad. Sérgio Paulo Rouanet. Pref. Jeanne Marie Gagnebin. 7. ed. São Paulo: Brasiliense, 1994, p. 226.

7 Mesmo que chrónos tenha sido a palavra comum entre nós, não é a única para designar o tempo entre os gregos. Outra é kairós, que significa 'medida', 'proporção', e, em relação com o tempo, 'momento crítico', 'temporada'. Uma terceira palavra é aión, a mesma que Platão usa para se referir à eternidade na passagem do Timeu.

8 BENJAMIN, Walter. Origem do drama trágico alemão. Trad. João Barrento. Lisboa: Assírio \& Alvim, 2004,p. 32.

9 GAGNEBIN, Jeanne Marie. História e narração em Walter Benjamin, op. cit., p. 14. 
Benjamin, a origem se afasta do entendido por fundação, início bíblico gênese - , haja vista o fato de não poder ser compreendida como o instante em que algo passa da inexistência à existência, mas como "algo que emerge do processo de devir e desaparecer". ${ }^{10}$ A origem é uma paralisação do momento histórico da formação inicial que atravessa o curso da história e absorve uma dada configuração no momento presente, representa um pulo para fora da esteira cronológica.

0 pulo original às memórias autobiográficas de Thomas Bernhard não representa uma volta saudosista de um passado quase perdido, tampouco é restauração do idêntico esquecido, mas é um apelo ao diferente, um ensaio extemporâneo de desvelamento de uma suposta origem absoluta - Beginn [começo] fechado e apreensível ou Entstehung [gênese] - é um recurso do sujeito cognoscente - tentativa de avaliação crítica do que resta do nacionalsocialismo e sua ideologia totalitária de fechamento - uma leitura do descontínuo. Desse modo, lembrando que esse Ursprung anacrônico atropela o tempo cronológico, Chrónos, em nome de uma leitura de tempos intensos ${ }^{11}$, Kairós, a escritura bernhardiana tece sua trilha em direção a um passado indesejado.

\section{EXPERIÊNCIA VILÃ}

Inicio então pelo começo que não é a origem, mas A causa [1975] e Uma criança [1982], obras que retratam os primeiros anos de vida de Thomas Bernhard. Entender como ele se tornou aquilo que ele é, a criação de seu mundo fantástico e fantasmático, através de uma infância interrompida em

10 BENJAMIN, Walter. Origem do drama trágico alemão, op. cit., p. 32.

${ }^{11}$ Mesmo que chrónos tenha sido a palavra comum entre nós, não é a única para designar o tempo entre os gregos. Outra é kairós, que significa 'medida', 'proporção', e, em relação com o tempo, 'momento crítico', 'temporada'. Uma terceira palavra é aión, a mesma que Platão usa para se referir à eternidade na citada passagem do Timeu; em seus usos mais antigos, aión designa a intensidade do tempo da vida humana, um destino, uma duração, uma temporalidade não numerável nem sucessiva, intensiva. Se chrónos é limite, aión é duração, é devir. 
nome da super-representação nacional-socialista. Esses dois textos mostram as circunstâncias familiares do escritor, como seu relacionamento difícil com a mãe e a ausência do pai. Bernhard só teve pelos avós uma real afetividade, marcada por admiração e respeito. Nestes dois volumes da autobiografia são tratadas, sobretudo, a infância e adolescência na cidade de Salzburgo, assim como sua entrada na escola nacional-socialista durante a guerra.

O pequeno Bernhard é retratado, nas primeiras páginas de Uma criança, como um menino astuto, irrequieto, sempre buscando experimentar - em um mundo de significantes dados que contribuíam para sua formação imagética: “Até hoje o atlas é minha leitura favorita. Pontos diferentes, fantasias diferentes."12 Lembrando que os primeiros livros infantis pecavam por um grande teor de esclarecimento, as gerações de obras que surgiram posteriormente puderam se redimir através das gravuras, ilustrações. 0 atlas, na contramão, surge através das cores, desperta a curiosidade e ajuda na elaboração dos fantasmas na criança: "A imagem colorida faz a fantasia infantil mergulhar, sonhadoramente em si mesma [...]. A imperiosa exigência de descrever, contida nessas imagens, estimula na criança a palavra."13 É a partir desta esfera que as crianças entram em um universo, delineando-o através de perguntas, passando por suas margens, recebendo estímulos e interagindo com o invisível, o inaudito, o impalatável, o imperceptível. Dão, assim, significação às coisas, desautomatizam o uso comum dos objetos, exercem, sem assim o saber, o papel daquele que cria. 0 devir-criança é, então, um movimento de desterritorialização total. Tomá-lo como ponto de partida se revela em uma transmutação de Chrónos, através das formas que dele resultam, a saber, o processo pelo produto, o movimento pela inércia, a experimentação pelo experimento. Ao entrar no mundo de significantes dados da linguagem, entra-se na história, entra-se nesse experimentum linguae, visto que na linguagem ainda é possível fazer uma experiência.

12 BERNHARD, Thomas. Origem. Trad. Sérgio Tellaroli. São Paulo: Companhia das Letras, 2006, p. 93.

13 BENJAMIN, Walter. A obra de arte na era de sua reprodutibilidade técnica. In: Magia e técnica, arte e política, op. cit., p. 241. 
0 artista precisa de material para a atividade criadora, ele recorre, então, às memórias fantásticas de sua infância. Bernhard mostra, através da escrita de si, no momento em que relata fatos da infância inicial, uma busca pela aventura; sua característica mais marcante é a curiosidade, ele sempre havia apreciado viajar para lugares novos e mostra constantemente admiração por pessoas simples como os artesãos e seu fazer manual ${ }^{14}$, o que sugere uma forma de resistência ao modelo cronológico de progresso da modernidade ao tempo linear e homogêneo e ao fazer tecnológico destruidor de todas as tradições. Assim, sintomaticamente, se revela uma autobiografia descontínua e contingente.

Além do grande apreço pela avó, Bernhard mostra também uma grande admiração pelo avô, pois é peça fundamental para o entendimento de todo aquele processo educativo e criativo, aparecendo frequentemente em sua obra como um contraponto positivo nos romances e peças ao lado dos parentes odiados. Johannes Freumbichler era escritor e sempre lhe incutia indagações sobre a vida, a música, a arte e filosofia. É possível relacionar, desta forma, sua valorização dos conselhos e histórias contados pelos avós, ao pensamento de Walter Benjamin em torno da chamada Erfahrung [experiência coletiva] - como uma tentativa do escritor austríaco de fazer menção aos ensinamentos culturais por parte de artesãos e das pessoas mais velhas dos vilarejos, visto que eram ainda aqueles que, numa tentativa de manter as tradições, asseguravam a necessidade de continuar a contar histórias para aprendizes e netos. Nessa ótica, Bernhard valoriza menos a transmissão cultural de ordem racional da escola que todo o legado de experiência do próprio avô: "Os passeios com o meu avô compunham-se sempre de história natural, filosofia, matemática, geometria, ensinamentos que traziam felicidade."15

\footnotetext{
${ }^{14}$ Nesse ínterim, o artesão desprendido de seu ritual lento e íntimo com o objeto de trabalho, desloca-se para as massas, onde se torna mais um entre vários. Walter Benjamin interpreta esse fenômeno como um indício do enfraquecimento da atividade narradora, haja vista o fato de que o artesão era aquele encarregado de passar adiante todo o legado cultural através de suas estórias.

15 BERNHARD, Thomas. Origem, op. cit., p. 60.
} 
Todo este pensamento já está contemplado no texto de Benjamin "Experiência e pobreza", em que o pensador berlinense expõe suas ideias em torno da Erfahrung, ou, da experiência coletiva que minguava na modernidade:

\begin{abstract}
Sabia-se exatamente o significado da experiência: ela sempre fora comunicada aos jovens. De forma concisa, com a autoridade da velhice, em provérbios; de forma prolixa, com a sua loquacidade, em histórias; muitas vezes como narrativas de países longínquos, diante da lareira, contadas a pais e netos. ${ }^{16}$
\end{abstract}

Benjamin demonstra que, sobretudo as [sobre] vivências dos campos de guerra, seriam as grandes responsáveis pela diminuição da chamada experiência coletiva, já que os soldados voltavam para casa com sua capacidade de relato quase destruída. Em consequência, surge a diminuição da capacidade narrativa, entrando em seu lugar a Erlebnis, ou uma experiência individual que nada tem a ver com a Erfahrung, e que é muito bem representada pela forma do romance moderno, em uma atividade narrativa fundada na invenção, não na transmissão.

Ao apontar para a necessidade de se continuar a transmitir a experiência, Bernhard está escovando a contrapelo uma história que insiste em avançar pela marcha cronológica e, assim, descarta os ensinamentos do vilão ${ }^{17}$, do camponês, dos mais velhos. 0 autor austríaco não propõe o desaparecimento

${ }^{16}$ BENJAMIN, Walter. Experiência e pobreza. In: Magia e técnica, arte e política, op. cit., p. 114.

17 Se pensarmos na palavra vilão como o habitante da vila, podemos perceber a arbitrariedade no surgimento de determinados significados pejorativos, visto que vilão é comumente associado ao significado de bandido. Em sua Genealogia da moral, Nietzsche faz uma análise morfológica da palavra alemã schlecht [ruim]. Em seus estudos, descobre que esta palavra é idêntica à schlicht [simples], de modo que ele chega à schlechtweg [simplesmente] e schlechterdings [simplesmente], o que mostra, desde suas origens, a função de designar o homem simples, plebeu. Tudo isso serve para demonstrar que as palavras nascem dentro de circunstâncias arbitrárias. Isso revela que a classe dominante acabou associando a classe plebeia ao conceito daquilo que é mau, o oposto da classe nobre. Por isso, os homens que se sentem e são privilegiados [classe nobre] é quem refletem o conceito de bom: "Esta me parece uma percepção essencial, no que toca a uma genealogia da moral; que tenha surgido tão tarde deve-se ao efeito inibidor que no mundo moderno exerce o preconceito democrático, no tocante a qualquer questão relativa às origens". NIETZSCHE, Friedrich. Genealogia da moral. Uma polêmica. Trad. Paulo Cézar de Souza. São Paulo: Companhia das Letras, 1999, p. 21. 
da experiência, mas deixa-a em aberto: como um processo, não como procedimento. Insere em seu discurso aquelas figuras que, segundo DidiHuberman, ainda apresentam resistência, relutância aos holofotes das luzes da glória e do poder, os vaga-lumes: "O valor da experiência caiu de cotação, mas cabe somente a nós, em cada situação particular, erguer essa queda à dignidade, à 'nova beleza' de uma coreografia, de uma invenção de formas."18 Se há um lampejo único de experiência, que seja percebido através destas singularidades, destes vaga-lumes: os camponeses, os aldeães, os mais velhos. É a isso a que Bernhard se refere.

\section{REPETIR PARA NÃO REPETIR}

O menino Bernhard desenvolve um traço, provavelmente graças à experiência traumática da Segunda Guerra Mundial: um discurso repetitivo, que se revela através de sua vontade de Erfahrung roubada. Em um determinado momento, em que o jovem Bernhard tem que se mudar para outra cidade, transcorre a passagem do fim de suas atividades criativas e estimuladoras da palavra para o começo do terror do controle. Nesse ponto ele descreve a entrada em sua vida da palavra nacional-socialismo: "Pela primeira vez ouvi a palavra Hitler e a palavra nacional-socialismo". ${ }^{19}$ Agora, no lugar da brincadeira entram pensamentos de suicídio que nascem da opressão exercida pelos professores de sua escola: "Pela primeira vez pensava em me matar." 20 Bernhard, assim, começa a repetir os signos linguísticos incansavelmente:

\footnotetext{
A convivência com os colegas de internato sempre foi uma convivência com o pensamento suicida; em primeiro lugar com o pensamento suicida, e somente depois com o objeto de aprendizado ou estudo. Na verdade, não fui o único a precisar conviver o tempo todo com o pensamento suicida durante meu período de aprendizado ou estudo. ${ }^{21}$
}

\footnotetext{
18 DIDI-HUBERMAN, Georges. A sobrevivência dos vaga-lumes. Trad. Vera Casa Nova e Márcia Arbex. Belo Horizonte: Editora UFMG, 2011, p. 127.

19 BERNHARD, Thomas. Origem, op. cit., p. 71.

20 Ibidem, p. 80.

21 Ibidem, p. 128.
} 
As variações que se repetem vão do sério ao lúdico, mas todas sempre musicalmente agressivas, revoltas. A repetição assemelha-se a uma dança circular, a um vinil arranhado numa vitrola, que desperta a curiosidade, de início, fascina pela falha da técnica, para depois irritar; com efeito, a música sempre foi um encanto e tema constante em sua vida: "Agora, eu aprendia o ofício de comerciante de livre e espontânea vontade, e estudava música também de livre e espontânea vontade; aprendia o oficio com o mesmo afinco e determinação com que estudava música." 22 Essa construção labiríntica, ela mesma, se revela através de sua musicalidade, mas representa um som que mais incomoda do que agrada. É um recurso estilístico que faz marcante uma ideia, que penetra o imaginário do leitor, uma tentativa do garoto de se libertar do trauma vivido na escola de orientação nazista.

Este trauma em sua infância e a compulsão por repetição resvala no que Freud chama de "compulsão à repetição", introduzida formalmente na teoria psicanalítica em Além do princípio do prazer (1920) ${ }^{23}$ :

\begin{abstract}
Em vista dessas observações, extraídas da conduta na transferência partir do destino das pessoas, sentimo-nos encorajados a supor que na vida psíquica há realmente uma compulsão à repetição, que sobrepuja o princípio do prazer. Também nos inclinaremos a ligar a essa compulsão os sonhos das vítimas de neurose traumática e o impulso que leva as crianças a brincar. ${ }^{24}$
\end{abstract}

Ao se deparar com os sonhos repetitivos de pacientes com neuroses traumáticas, como por exemplo, de guerras, Freud passa a questionar sua teoria dos sonhos, pela qual afirmava que todos os sonhos seriam uma realização de desejo. Ele analisa a função desses sonhos, que repetem cenas traumáticas,

22 BERNHARD, Thomas. Origem, op. cit., p. 300.

23 É possível precisar dois momentos específicos na teorização freudiana sobre a repetição. São eles: Recordar, repetir e elaborar [1914] e Além do princípio de prazer [1920]. Contudo, Freud faz menção a este tema em diversas ocasiões ao longo de sua construção teórica, seja antes de 1914 ou posteriormente a 1920.

24 FREUD, Sigmund. Além do princípio do prazer. In: Obras completas, vol. 14. Trad. Paulo César de Souza. São Paulo: Companhia das Letras, 2010, p. 183. 
como dolorosas. Para ele, tais sonhos teriam a função de desenvolver a angústia retroativamente, onde esta faltou.

A repetição que faz parte de sua arte do exagero é uma característica constante na obra, revelando-se quase monomaníaca, é uma espécie de brincadeira sádica e pueril de Bernhard com o leitor:

\begin{abstract}
A repetição obsessiva embaralha o sentido atribuído às palavras. É muito conhecida uma brincadeira - de crianças, sobretudo - que consiste em repetir à exaustão um determinado significante, rapidamente, sem pausa mesmo para respirar, provocando de uma hora para outra o esvaziamento do significado atribuído àquele significante: o signo está temporariamente desfigurado. Este procedimento torna-se estruturalmente decisivo em Bernhard e em sua concepção de estética e de verdade, de seu realismo. ${ }^{25}$
\end{abstract}

A Übertreibungskunst [arte do exagero] pode ser lida como um dos pontos centrais desta estética, levada em consideração por vários estudiosos de sua obra. A realidade é convocada hiperbolicamente, tornando-se condição sine qua non para a elaboração sinuosa do mundo. Assim guia Bernhard sua escrita de si, através do torpor da arte do exagero e de uma estética da repetição, desfigura a autobiografia, prefere mentir, em nome da ficção: "Em sua autobiografia, Bernhard não relata, como se espera, completamente de forma autêntica, ele exagera. Temos aqui a arte do exagero." ${ }^{26} 0$ exagero e a repetição representam um grito sufocado do jovem Bernhard que tenta se livrar do trauma, mas apenas o consegue em forma de balbucio agressivo, ele já não consegue se comunicar com fluência porque os signos linguísticos lhe ocorrem de modo fugidio; mesmo assim, continua o relato traumático, ele consegue fazer uma releitura da história, que é revelada dialeticamente em um momento de assombro, espanto - momento presente - sempre cortada por

25 FLORY, Alexandre Villibor. Sopa de letras nazista. A apropriação imediata do real e a mediação pela forma na ficção de Thomas Bernhard. Tese de Doutorado - USP, São Paulo, 2006, p. 97-98.

26 „In seiner Autobiografie wird natürlich nicht völlig authentisch berichtet, hier wird übertrieben. Und Thomas Bernhard übertreibt, es handelt sich aber um eine Übertreibungskunst." SCHMIDT-DENGLER, Wendelin. Der Übertreibungskünstler. Studien zu Thomas Bernhard. Wien: Sonderzahl, 1997, p. 1. 
diferenças. Expõe desta forma as reminiscências do fantasma nacional-socialista que reverberam. Aponta para um sistema de ensino que ainda se fazia guiar tacitamente pelo mito nazista.

\section{O CORPO VIGIADO E PUNIDO}

O papel do adulto e das instituições escolares deveria ser o de proporcionar à criança um maior significado e espaço para que possam acontecer a brincadeira e fantasia livres. No entanto, são eles que inibem, através da vigilância e punição, sua liberdade. A escola austríaca no período hitlerista não se configura como uma instituição do saber, em que professores despertariam em seus pupilos a curiosidade e fantasia pela vida, ao contrário, ela é vista pelo menino Bernhard como um palco de horrores, comparada a uma prisão: “O internato é para o recém-chegado um cárcere projetado com refinamento contra ele, e, portanto, contra a totalidade de sua existência, uma construção mesquinha contra seu espírito." 27 Assim, Bernhard aponta em sua Origem que instituições como escola, prisão e clínica não se diferem quanto à vigilância e punição, ao controle dos corpos. Observação crítica que Michel Foucault irá tratar, sobretudo, em seus livros Vigiar e punir e História da sexualidade.

Neste sentido, o sistema penitenciário estará no cerne das análises de Foucault para entendermos como os sujeitos são legitimados a partir destas instituições de poder. ${ }^{28}$ A comparação física das escolas e das prisões surge,

27 BERNHARD, Thomas. Origem, op. cit., p. 123.

28 Ao analisar as prisões, Foucault aponta que elas possuem mecanismos internos de repressão e punição que ultrapassam o castigo da "alma", investindo na regulação do corpo do detento pela coação estimulada por uma educação total, reguladora de todos os movimentos do corpo. E nesse sentido, além da privação da liberdade, elas executam uma transformação técnica dos indivíduos. A tecnologia política do corpo não é percebida nas instituições devido às diversas formas em que ela se cristaliza. Não sendo violenta ou explícita, é introduzida, segundo Foucault, como uma "microfísica do poder", que se posiciona entre as instituições e os próprios corpos. Visando a atingir o ideal de "ortopedia social", em que a permanente vigilância representa tática de eficácia, Foucault localiza na prisão um dos espaços sociais apropriados para produzir o "corpo dócil”, economicamente produtivo, socialmente civilizado, politicamente disciplinado e culturalmente devotado à prática e às 
para o pensador francês, a partir de seu modelo arquitetônico. Classes distribuídas lado a lado sem nenhuma comunicação, janelas gradeadas, refeitório comunitário, muros altos e com grades, portões sem nenhuma visibilidade para o lado externo à escola. A construção das escolas obedece a quase todas essas disposições e com uma particularidade importante: a posição da sala da diretoria permite ter uma visão geral de todo estabelecimento, o que Foucault chama de panóptico. 0 panóptico é não somente característico das prisões, mas, também, se encontra nas instituições escolares. Mesmo que não apresente efetivamente todas as características descritas, a funcionalidade do posicionamento da sala da diretoria se relaciona com um modelo de vigilância. Nas escolas todo ato entendido como transgressor é avaliado e fica passível de punição.

No volume $A$ causa surge o diretor Grünkranz, o olho inquisidor desse panóptico, o diretor do internato nazista que Bernhard frequentou. Grünkranz é um oficial-SA ${ }^{29}$, modelo que tentava fazer os alunos se tornarem parte do regime de Hitler, forçando-os a cantar músicas em louvor ao Führer.

\begin{abstract}
Assim sendo, sobretudo dois medos imperavam à época no aluno que eu era: por um lado o medo de tudo e de todos no internato, mas principalmente o medo do Grünkranz, surgindo e punindo sempre de forma inesperada, com toda sua infâmia e astúcia militar, era oficial-modelo, oficial modelo do exército e da SA. ${ }^{30}$
\end{abstract}

Leia-se aqui o poder exercido pelo diretor Grünkranz não como uma forma negativa, em que o mesmo se revela de modo negativo através da punição, do castigo. Mas, sim, como uma forma positiva, de controle do corpo dos alunos,

razões do Estado. Da mesma forma, podemos ler o sistema escolar, especialmente no período da Segunda Guerra, em que as forças do pensamento nazista primavam pelo controle não só ideológico, mas também do corpo, de modo que a ideologia nacional-socialista pôde ser instaurada desde a infância, através da escola.

29 Sturmabteilung, abreviado para SA [em alemão "Seção Tempestade", "Destacamento Tempestade" ou "Seção de Assalto"] usualmente traduzida como "Tropas de Assalto", foi a milícia paramilitar nazista durante o período em que o Nacional Socialismo exercia o poder na Alemanha.

30 BERNHARD, Thomas. Origem, op. cit., p. 132. 
de sua domesticação e preparação para o controle nacional-socialista, dentro da lógica biopolítica31. Em A causa, segundo Dávalos, acerca da autobiografia de Bernhard:

\begin{abstract}
A crítica feita à escola pode ser entendida como uma crítica a toda sociedade austríaca, aliás, segundo o autor, só mudando a primeira, muda-se o país, logo, se o sistema de educação nazista e católico-democrático são iguais em sua concepção, as mudanças estando apenas na aparência, a continuidade entre sociedade totalitária e democrática estaria implícita, disso viriam então as advertências anteriormente mencionadas com relação à volta do nacional-socialismo, pois sua essência continuaria na base da sociedade. ${ }^{32}$
\end{abstract}

A escola é, dessa forma, “[...] um espaço fechado, recortado, vigiado em todos os seus pontos, onde os indivíduos estão inseridos num lugar físico onde os menores movimentos são controlados onde todos os acontecimentos são registrados [...]". ${ }^{33}$ Esse tipo de vigilância permite à diretoria um controle sobre tudo o que acontece. É na escola de Bernhard, pois, onde o grande trauma aflora: "Os métodos de castigo doutrinários no internato assim como na escola no ensino fundamental e, posteriormente, no ensino médio, teriam destruído o intelecto e lesado a alma de Bernhard."34

É importante salientar que o escritor austríaco impõe questionamentos não somente acerca do sistema de ensino antes e durante a Segunda Guerra, mas também ao que se seguiu, mostrando que os restos do nacional-socia-

310 conceito de biopolítica foi pensando, primeiramente, por Michel Foucault, no primeiro volume de sua História da sexualidade. A ideia de biopolítica veio se juntar às reflexões sobre as práticas disciplinares, ambas técnicas de exercício de poder, particularmente a partir do século XVIII e XIX. As disciplinas se voltavam para o indivíduo, e para o seu corpo, para a sua manipulação e adestramento através das diversas instituições modernas que perpassavam o indivíduo - como a escola, a fábrica, o hospital, a prisão - Eram instituições que domesticavam, vigiavam e puniam os corpos e os tornavam aptos à produção industrial, ao controle do Estado, ou seja, peças fundamentais para a produção capitalista.

32 DÁVALOS, Patrícia Miranda. Ficção e autobiografia. Uma análise comparativa das narrativas de Thomas Bernhard. Dissertação de Mestrado - USP, São Paulo, 2009, p. 28.

${ }^{33}$ Foucault, Michel. Microfísica do poder. Trad. Roberto Machado. Rio de Janeiro: Graal, 1998, p. 174.

34 „Die doktrinären Lehr- und die grausamen Züchtigungsmethoden im Internant wie auch in der Hauptschule und dem anschließend besuchten Gymnasium hätten, so Bernhard den Geist gestört und die Psyche geschädigt." HOELL, Joachim. Thomas Bernhard, op. cit., p. 30. 
lismo ainda se encontram na base da educação. Ele apresenta, dessa forma, a importância da educação na formação de uma sociedade pós-guerra. Adorno, em seu texto "A educação após Auschwitz", ressalta que a principal meta da educação deve ser a de evitar que Auschwitz se repita: "A exigência de que Auschwitz não se repita é a primeira de todas para a educação". ${ }^{35}$

A estética da repetição de Bernhard, através de sua leitura dialética da origem, é a chave estilística que interroga e torna inoperante o discurso nacional-socialista que perdura. Ele se apropria de uma das marcas do organizado pensamento nazista que também se valia do discurso repetitivo. Era a forma encontrada pelos aliados de Hitler para fazer o mind control na população.

O sentido das fórmulas fascistas, da disciplina ritual, dos uniformes e de todo aparato pretensamente irracional é possibilitar o comportamento mimético. Os símbolos engenhosamente arquitetados, próprios a todo movimento contra-revolucionário, as caveiras e mascaradas, o bárbaro rufar dos tambores, a monótona repetição de palavras e gestos são outras tantas imitações organizadas de práticas mágicas, a mimese da mimese. ${ }^{36}$

É dessa forma que Thomas Bernhard, através de seu pulo tigrino ${ }^{37}$ ao passado, em sua Origem, escova a história a contrapelo, ao usar a tática do inimigo, com a ajuda de sua estética da repetição, desvela o discurso nacionalsocialista que ainda ecoa, apontando no tempo de agora para uma história em ruínas, em que o mito nazista ainda se faz presente em nossa sociedade. Giorgio Agamben, fazendo também uma leitura destes restos, um insistente suspiro nacional-socialista, aponta para o perigo iminente: "De um ponto de

35 ADORNO, Theodor. Educação após Auschwitz. In: Educação e emancipação. Trad. Wolfgang Leo Maar. Rio de Janeiro: Paz e Terra. 1995, p. 119.

${ }^{36}$ ADORNO, Theodor; HORKHEIMNER, Max. Dialética do esclarecimento. Trad. Guido Antonio de Almeida. Rio de Janeiro: Jorge Zahar, 2006, p. 152.

37 Walter Benjamin irá denominar de salto tigrino ao passado toda apropriação do mesmo não saudosista, mas, sim, dialético, de modo que o presente não seja mais o mesmo. Ele propõe outra concepção do tempo que não é o tempo "homogêneo e vazio" das ciências históricas e naturais. A ideia de progresso histórico é rechaçada, e em seu lugar, sugere que tomemos o tempo como algo que permite instantes de ruptura, de iluminações contínuas. 0 Jetztzeit, tempo de agora, possibilita aos oprimidos que mudem o discurso consagrado, dos grandes nomes, da história tradicional. 
vista estritamente político, fascismo e nazismo não foram superados e é sob o seu signo que vivemos ainda". ${ }^{38}$ A existência, principalmente na Europa, de partidos políticos de orientação de extrema direita, é um bom exemplo deste eco. Grupos de neonazistas povoam não só cidades europeias, mas também norte-americanas e até mesmo brasileiras.

Este é o grande objetivo da estética sinuosa de Bernhard: reeducar-nos para a arte de pensar. A estética da repetição e exagero representa a construção de um novo pensamento enviesado que relê a história e afirma o sujeito cognoscente e sua rebelião no momento presente.

${ }^{38}$ AGAMBEN, Giorgio. A comunidade que vem. Trad. António Guerreiro. Lisboa: Editorial Presença, 1993, p. 50. 